\title{
"Bomuldens land"
}

\author{
Jean Toomers sorte agrarmodernisme
}

\author{
Peter Mortensen
}

\begin{abstract}
Begyndende med Sartoris opdagede jeg at mit eget lille frimarke af fodrene jord var vard at skrive om og at jeg aldrig ville leve lange nok til at udtomme det.

William Faulkner, Interview with William Faulkner, 1926-1962
\end{abstract}

\section{$I$}

I et essay om James Joyce udkaster Fredric Jameson en teori, som knytter den litterære modernisme til det 20. århundredes storbycivilisation:

Det paradoksale ved modernismens historiske erfaring er at den meget præcist markerer det tidspunkt hvor Naturen - det ikke- eller anti-menneskelige - overalt er ved at blive fortrængt eller ødelagt, udstødt og elimineret, af den menneskelige praksis og produktivitet. Den store modernistiske litteratur - fra Baudelaire og Flaubert til Ulysses og videre - er bylitteratur: dens genstand er derfor det anti-naturlige og menneskeliggjorte par excellence, et landskab som overalt er resultatet af menneskelig arbejdskraft, hvori alting - selv det tidligere naturlige, græs, træer, vore egne kroppe - i sidste instans er menneskeskabt. ${ }^{\text {I }}$

"Den store modernistiske litteratur [...] er bylitteratur": Jamesons postulat forekommer ukontroversielt, men i realiteten er forholdet mellem modernismen, storbyen og provinsen mere komplekst og modsætningsfyldt end som så. Når Jameson ligesom Malcolm Bradbury i et andet indflydelsesrigt essay begrænser "modernisme" til "en særligt urban kunst," indsnævrer han bevægelsens spændvidde betragteligt, idet han kolporterer en overraskende en-dimensionel opfattelse af "det moderne." ${ }^{2}$ Jameson og Bradbury undervurderer begge, i hvor høj grad den litterære modernisme "var modmoderne og rationalitetskritisk," og i hvilket omfang selv tilsyneladende "anti-moderne" kulturelle bevægelser stræber mod en "anden modernitet." 3 Men i stedet for blot at dikotomisere "moderne" storbylitteratur og "anti-moderne" provinslitteratur kan man som den tyske komparativist Norbert Mecklenburg anlægge det synspunkt, "at modernitet og regionalitet ikke nødvendigvis må udelukke hinanden.” 4 Polariteten mellem land og by, Gemeinschaft og Gesellschaft, mistede ingenlunde sin relevans efter det moderne gennembrud - snarere tværtimod. Modernismen kan tage form som en besindelse på "det nye," men dens udgangspunkt kan også være en stædig beslutning om "at blive i provinsen," som Martin Heidegger udtrykte det. 5

Fyrtårnet blandt provinsielle amerikanske modernister var Nobelpristageren William Faulkner, som skyede storbyen som pesten og i et interview i 1956 beskrev sin litterære virksomhed som en metaforisk opdyrkelse af sin "fædrene jord." Inden da havde Sherwood Andersons Winesburg, Ohio (1919) opnået anseelig popularitet (den oversattes bl.a. til dansk i I934 af Elias Bredsdorff), og mange vil også kende til digteren Allen Tate, et toneangivende medlem af den gruppe af forfattere og kritikere som i begyndelsen af 1920'erne opstod ved Vanderbilt-universitetet i Nashville, Tennessee, først som udgivere af det litterære avantgarde-tidsskrift The Fugitive (1922-25) og senere som ophavsmænd til det polemiske kampskrift I'll Take My Stand (1930). Denne gruppe af "sydstatsagrarer" ("Southern Agrarians") rekrutterede deres medlemmer fra en forholdsvis snæver kreds af ligesindede, men hvide forfattere havde ikke patent på storbydespekten, og lignende 
provinsforankrede agrarmodernismer opstod inden for andre og mindre bornerte miljøer. En forfatter, som i høj grad medvirkede til at placere Syden, og specielt det landlige sorte Syden, på det litterære landkort i 1920'erne, var afroamerikaneren Jean Toomer (I894-1967). Ærkeracisten Tate havde ikke for vane at akklamere sorte kunstneres bedrifter, men han udtrykte dog sin beundring for Toomer og især for dennes mesterværk, Cane (1923). Toomer, skrev Tate, var ikke blot at betragte som "den dygtigste sorte forfatter som endnu har vist sig på den amerikanske scene" - selv bedømt efter den højeste målestok måtte Cane anerkendes som et værk, der ville "udfordre de bedste moderne forfattere" og blive "yderst vigtig for litteraturen."7

\section{II}

Amerikanske agrarmodernister vender bymodernismen på hovedet, idet de benytter eksperimenterende teknikker til at gestalte fragmentariske og stærkt værdiladede indtryk af livet i tilbagestående landbosamfund i højindustrialismens tidsalder. At Cane i dag regnes blandt den moderne amerikanske litteraturs klassikere skyldes ikke blot, at Toomer i løbet af I960'erne og 70'erne kanoniseredes som et sort litterært koryfæ, men også at Cane er en formelt eksperimenterende kollage skrevet $\mathrm{i}$ et selvrefleksivt, elliptisk og symbolladet sprog, som blander lyrik, kortprosa og drama til en stærkt suggestiv, genremæssigt ubestemmelig syntese, der har virket nærmest hypnotiserende på de seneste årtiers amerikanske litteraturkritikere. Toomer placerede sig i begyndelsen af I920'erne i krydsfeltet mellem den afroamerikanske Harlem-Renæssance og det hvide avantgardemiljø omkring bl.a. Waldo Frank, Hart Crane og Paul Rosenfeld. Deltagerne i disse bevægelser delte en forhåbning om, at det hensygnende engelske sprog kunne genvitaliseres gennem kreative sproglige forskydninger, kortslutninger og forvrængninger og ikke mindst ved litteraturens inkorporering af ikke-litterære, excentriske og underlødige fraseologier hentet hos sociale og især etniske minoriteter. ${ }^{8}$ Den fragmenterede kollageform og ønsket om sprogligt og stilistisk at "gøre noget nyt"9 gør Cane til et veritabelt katalog over perio- dens avantgardeformer, fra Picasso-inspireret litterær kubisme til Joyceansk bevidsthedsstrøms-prosa, poetisk imagisme à la Ezra Pound og ekspressionistisk drama i stil med Eugene O'Neill. Et andet innovativt element i Cane er brugen af etnisk specifikke udtryksformer som gospel, blues, "call and response" og naturligvis jazz. Cane er ikke for ingenting et produkt af den periode (I920'erne), som man har kaldt "the Jazz Age." Ud over at de enkelte digte og noveller indeholder mangfoldige henvisninger til jazz, jazzmusikere og jazzklubber lader teksten, som i udpræget grad mangler linearitet og overordnet plotstruktur, sig også tolke jazzæstetisk, som en række improvisatoriske variationer over tilbagevendende temaer.

Toomer kombinerer ligesom andre agrarmodernister urbanisme med kulturpessimisme, et hypersofistikeret æstetisk udtryk med en nostalgisk længsel efter forankring, jordforbindelse og rodfæstning - alle de tilstande, som konnoteres af det vanskeligt oversættelige engelske ord "soil” (jord, grund, muld). Toomers forfatterskab tager historisk udgangspunkt i den sorte befolknings "Store Udvandring” ("Great Migration") fra de agrare sydstater til det industrialiserede Nord omkring Første Verdenskrig, samt i en personlig modsatrettet bevægelse fra storbyen tilbage mod provinsen. Toomer stammede fra Syden og havde i løbet af sin omflakkende ungdom boet i New York, Washington D. C. og Chicago, men havde også studeret landbrugsvidenskab $\mathrm{i}$ Wisconsin og Massachusetts. I sommeren og efteråret I92I vikarierede han som forstander på en landbrugsskole i Sparta, Georgia, og det var ifølge hans eget vidnesbyrd denne oplevelse, som galvaniserede hans talent og katalyserede hans litterære ambitioner:

Et besøg i Georgia sidste efterår var udgangspunktet for næsten alt værdifuldt som jeg har udrettet. Jeg hørte folkesange fra sorte bønders læber. Jeg så den rige mørke skønhed som jeg havde hørt mange falske udtalelser om, og som hidtil havde gjort mig noget skeptisk. Og en dyb del af min natur, en del som jeg havde undertrykt, sprang til live og kom dem i møde. $\mathrm{Nu}$ kan jeg ikke længere opfatte mig selv som fjern og isoleret. Mit synspunkt er ikke ændret; det har uddybet og udvidet sig. ${ }^{\text {IO }}$ 
I lighed med andre litterære agrarer kanaliserer Toomer herefter avantgardens energier i retning af en civilisationskritisk oprustning mod Nordens "mekaniske civilisation" og et indædt (om end ambivalent) forsvar for de tilbageværende rester af Sydens truede almuekultur. II Tonen i dette projekt svinger mellem defaitistisk resignation og konfrontatorisk kamplyst. Toomer understregede det elegiske element i Cane, da han beskrev teksten som en mistrøstig "svanesang" for en døende kulturform: "Blandt de sorte gik tendensen også i retning af den lille by og derefter mod byen - og industri og handel og maskineri. Folkeånden vandrede ud for at dø i den moderne ørken. [...] Cane var en svanesang. Den var en sang om en afslutning." 52 Men i sine mere håbefulde stunder placerede Toomer Canes kulturelle arkæologi som led i en (mod)moderne kampagne for at vende industrisamfundets Titanic før dets uundgåelige forlis: "Amerika har brug for disse elementer," skriver han i I922 om den jordfæstede kultur blandt sorte "bønder": "De er ved at forsvinde. Lad os gribe og holde dem mens der stadig er tid." ${ }_{33} \mathrm{Og}$ i det upublicerede essay "The South in Literature" (I923) karakteriserer Toomer ligeledes "sydstatsnegerens bonde-tilpasningsrytme" som en positiv og potentielt frelsende modvægt til Nordens foretagsomt-krigeriske pionerånd:

Syden ejer en bondestand som er forankret i jorden, og som hverken Norden eller Vesten har. Sydstatsbonden har en grundlæggende tilpasning til sit fysiske miljø (i skarp modsætning til den nordlige pioners rastløse utilpassethed), hvis udtryk den almene kultur stærkt behøver. Og fra Sydens landbrugssamfund strømmer et rigt og komplekst liv. ${ }^{\text {I4 }}$

III

Kritikeren Charles Larson har betegnet Cane som

En enestående tekst både i amerikansk litteratur og i verdenslitteraturen. [...] Cane er et af de mest nyskabende værker i det 20. århundredes amerikanske fiktion - et monument $i$ amerikansk litteratur, som foregriber de efterfølgende eksperimenterende værker af John Dos Passos og William Faulkner. Den amerikanske avantgarde-roman begynder ikke med disse forfattere, men med Jean Toomers Cane. ${ }^{\text {Is }}$
Sikkert er det i hvert fald, at ingen sorte forfattere, og formentlig heller ingen hvide, nogensinde havde skrevet om provinsen helt som Toomer gjorde i Cane. Teksterne, som udgør kollagen, foregår dels blandt nyligt emigrerede neurastenikere i Nordens industribyer (Washington D. C. og Chicago), dels blandt agerbrugere i landsbyen Sempter, Georgia, som er Toomers navn for Sparta i Hancock County og hans pendant til Andersons Winesburg, Ohio. I Georgia-teksterne, som udgør Canes første og tredje del, forsøger Toomer gennem en række enigmatiske billeder, skitser, vignetter og fragmenter at indkredse livsbetingelserne for småbønder og landarbejdere i Georgia anno ca. 1920. Cane afstedkom udbredt forvirring ved udgivelsen i 1923 , og det mest slående ved disse tekster er stadig deres ekstreme formelle og stilistiske heterogenitet og deres udtalte mangel på kohærens. Ét er, at Toomer konstant veksler mellem lyrik, kortprosa og dramatik, uden på noget tidspunkt at rangere en genre over de andre. Et andet er, at han forsager brugen af et fast karaktergalleri eller en gennemgående hovedperson, og at han $\mathrm{i}$ modsætning til f.eks. Sherwood Andersen undlader at anvende en forklarende episk struktur eller overordnet rammefortælling, som kan sammenkæde de forskellige fragmenter til et sammenhængende hele. Fortællerperspektivet oscillerer skizofrent mellem tredje og første person, idet tilsyneladende objektivt-alvidende synsvinkler kombineres med mere subjektivt-begrænsede fortælleformer. En dramatiseret jeg-fortæller, hvis omstændigheder til forveksling minder om Toomers egne, optræder kort $\mathrm{i}$ "Fern" og "Song of the Son," men dennes rolle forbliver dog særdeles uklar, og han tiltvinger sig aldrig overordnet autoritet over fortællingen. Gennem en nærmest kubistisk sammenskrivning af inkommensurable perspektiveringer gør Toomer det vanskeligt, for ikke at sige umuligt, for læseren at forestille sig Canes allotropiske fortælleinstans som en integreret kognitiv helhed. ${ }^{16}$ Læseren overlades i vid udstrækning til sig selv og tvinges, som så ofte i "scriptible" modernistiske tekster, til at deltage aktivt i den hermeneutiske proces. Ikke alt er dog kaos, og visse betydningsmønstre lader sig trods alt dechifrere. En del af Canes vigtigste tekster ("Karintha," "Becky," 
“Carma," "Fern," “Blood-Burning Moon”) kredser således om karismatiske kvindeskikkelser, hvis forsyndelser mod den gældende seksualmoral resulterer i voldelige udskejelser blandt mændene $\mathrm{i}$ deres omgangskreds. I en række andre tekster ("Georgia Dusk," "Esther," "Conversion") befatter Toomer sig med Sydens religiøse traditioner, ritualer og konflikter. For så vidt at teksterne i Cane "hænger sammen", ligger kontinuiteten dels i disse tematiske sammenfald, dels i Toomers anvendelse af symbolladede ord og begreber, som f.eks. "soil" (jord/muld), "dusk" (tusmørke) og “cane” (sukkerrør).

Man har foreholdt Toomer, at hans impressionistiske provinskarakteristik omdanner Sempter til en surreel drømmeverden, og at han negligerer den historiske erfaring for Sydens sorte landbefolkning, som i I920'erne plagedes af ugunstige klimaforhold, dårlige arbejdsbetingelser, faldende landbrugspriser og indgroet racistisk forskelsbehandling. ${ }^{17}$ Men retfærdigvis må det anføres, at Cane faktisk strejfer en del af samtidens kontroversielle sociale problemstillinger. Social marginalisering behandles, om end forholdsvis implicit, i skitsen af Becky, en hvid kvinde som på grund af sine to mulatsønner forvises fra både det hvide og det sorte samfund. Racevold tematiseres endvidere eksplicit i adskillige tekster, mest spektakulært i novellen "Blood Burning Moon," som tager udgangspunkt $\mathrm{i}$ en sort-hvid menage á trois og ender med en gruopvækkende lynchning. Alligevel står det forholdsvis klart, at Toomer afviser, og bevidst søger at underminere, den sociologisk baserede provinsbeskrivelse og den deterministiske antropologi, som f.eks. stadig ligger til grund for Winesburg, Ohio. Toomers mæcen Waldo Frank pointerede denne forskel mellem Toomer og andre sorte og hvide forfattere, da han i Canes oprindelige forord erklærede, at "for Toomer er Syden ikke et problem som skal løses; den er et stykke skønhed som skal besynges; den sorte fra Georgia er ikke en undertrykt sjæl som skal opløftes; han er materiale for et prægtigt maleri.' 18

Toomer foretrækker mytopoeia for empiri; Sempter betragtes nok som et konkret sted hjemsøgt af raceundertrykkelse og klasseulighed, men anskues i endnu højere grad sub specie aternitatis, som et sammensurium af uudgrundelige karaktertyper tilhørende en arkaisk, tusmørkeindhyllet, næsten forsvundet verden. Toomers menneskeopfattelse anerkender nok betydningen af "ydre" faktorer - køn, klasse, race osv. - men helhedsindtrykket er alligevel den skærende kontrast mellem Sempter-borgernes miserable økonomiske omstændigheder og deres indre livs mystiske rigdom. Denne dobbelthed illustreres af Canes symbolske omdrejningspunkt - den kompakt-højstemte skildring af sukkerrørsplanten ("cane"), som i den oprindelige udgave tryktes på forsiden:

Oracular.

Redolent of fermenting syrup,

Purple of the dusk,

Deep-rooted cane.

Ligesom sukkerrørsplanten hæver sig fra mulden mod den glødende aftenhimmel, således er Toomers sydstatsbønder både børn af tiden og indbyggere $\mathrm{i}$ et mytisk, transcendent "evigt Syden." I9 Samfundsvidenskab og klassekamp har kun begrænset anvendelsesværdi for Toomer, for hans primære ærinde er ikke at afdække social uretfærdighed, men snarere at celebrere og om muligt revitalisere provinsens landbrugssamfunds "rige" og "komplekse" liv. Sorte og hvide forkæmpere for "racemæssig fremgang" ("racial uplift") var (og er) skuffede over Cane, for teksten er ikke at betragte som sociologisk problemlitteratur, men som orakuløs besyngelse. Toomer bedriver ikke klassekamp, men åndelig politik; han anvender ikke den dokumentariske, men den "mytiske metode." 20

IV

Toomer kan ikke uden videre anklages for at idyllisere hjemstavnen og provinslivet - dertil er teksterne i Cane for voldelige og bizarre. Toomer modstiller ikke blot by og land som tomme modsætninger, men han understreger - og overdriver - konsekvent de sider af provinsen, som får Sempter, Georgia, til at fremstå som den livgivende antitese til en dødsmærket industrimodernitet. Sukkerrørsplanten giverToomer det elementære metaforiske redskab, hvormed 
han udvikler sin bondekarakteristik. På den ene side symboliserer denne "deep-rooted" plante bundethed til naturens og kroppens organiske processer. Eksistensgrundlaget i Cane er ubestridt landarbejdet, dvs. såningen, høstningen og forarbejdningen af bomuld og sukkerrør, en årstidsbestemt proces som besynges i storladne, nærmest sakrale toner. Savmøllen, som nævnes i "Karintha", og den hestetrukne høstmaskine $i$ "Reapers" er tegn på en snigende modernisering, men i "bomuldens land" foregår størstedelen af markarbejdet stadig ifølge Toomer på gammeldags manér, ved metoder som gengives fintfølende (om end uspecifikt) i tekster som "Cotton Song," hvor Toomer forsøger at indfange rytmen i arbejdet med tunge bomuldsballer:

Come, brother, come. Lets lift it;

come now, hewit! roll away!

Shackles fall upon the Judgment Day

But lets not wait for it. ${ }^{2 \text { I }}$

Cane etablerer et monument for arbejds-, mentalitets- og livsformer, som industrimoderniteten langsomt, men sikkert, bortrationaliserer, og Toomer romantiserer utvivlsomt i nogen grad det manuelle landarbejde som ufremmedgjort kontakt med jorden, "the soil." Kontakten med jorden genererer det overskud af sensuel vitalitet, som udmærker Sempters sorte provinsmennesker, og som giver Cane en til tider chokerende kødelig frisson: "At kønnene er skabt for at parre sig," skriver Toomers fortæller, "er Sydens praksis. Især sorte folk blev skabt til at parre sig. Og det er sorte folk som jeg har talt om indtil nu." 22 "Skabt for at parre sig" ("made to mate") er ikke mindst tekstens kvinder, for Canes første del samler især en række skitser af sorte kvindeskikkelser, hvis ubetvingelige livslyst og næsten ktoniske seksualitet udæsker konventionelle kristne moralbegreber. Åbningsteksten "Karintha" henviser til en ung pige, hvis spontane livsenergi - "Karintha, som tolvårig, var et vildt lysglimt som fortalte de andre folk hvad det vil sige at leve" ${ }_{23}$ - får byens religiøse autoritetsfigurer og selv præsten til at se igennem fingre med hendes seksuelle eskapader, og "Carma" portrætterer endnu en kvinde, som ikke lader sig kujonere af modgang og fordømmelse: "Hvem var hendes mand? Skulle hun ikke tage andre, denne Carma, stærk som en mand, hvis historie som jeg har fortalt var det groveste melodrama?" 24 "Fern" er navnet på og historien om en sfinksagtig Sempterkvinde, hvis jomfruelige natur forbliver uberørt på trods af hendes mange elskere: "det forekom som om hele landskabet flød ind i hendes øjne. Flød ind i dem med hele det sydlige Georgias bløde og apatiske rytme." ${ }^{25} \mathrm{Og}$ i den morbide "BloodBurning Moon" udløses katastrofen af, at hverken Louisas hvide elsker Bob Stone eller den sorte Tom Burwell kan opfatte hendes kropslige generøsitet som andet end utroskab. Toomer mener tilsyneladende, at de sorte kvinder er mindre fremmedgjorte over for naturens grundvilkår end mændene, men han nøjes ikke med at karakterisere provinsen som seksuelt friere end storbyen: Han fejrer den sorte provinskvindes animalisme som et livgivende alternativ til den sterile protestantiske arbejdsmoral. Hvis Toomer omvendt kan siges at flirte risikabelt med post-romantikkens primitivistiske stereotypier, er flirten dog særdeles selvbevidst, og tekstens stilistiske idiosynkrasier hæver den altid over det rent klichéagtige.

Med sin agrarprimitivisme indskriver Toomer sig $\mathrm{i}$ et problem- og konfliktfyldt felt; hans négritude udfordrer såvel de prominente sorte byintellektuelle (f.eks. W. E. DuBois og Alain Locke), der krævede en tækkelig sort kunst, som de samtidige hvide æsteter (fra Pablo Picasso til Carl van Vechten og Gertrude Stein), som tappede den afrocentriske dialekts subversivitet. Men sukkerrørsplanten er både “deep-rooted” og “oracular,” både jordfæstet og metafysisk - et naturligt fænomen, men også et bindeled mellem den sanselige og den oversanselige verden. Ifølge Toomer er animalsk vitalitet ikke ensbetydende med åndløshed, for homo provincialis er også homo religiosus. Toomer var selv en søgende sjæl, som tidligt interesserede sig for "nyreligiøse" fænomener, og under et ophold i Frankrig i 1924 fandt han åndeligt fodfæste inden for miljøet omkring den armenske guru George I. Gurdjieff, hvis esoteriske selvudviklings-filosofi Toomer herefter advokerede blandt andre amerikanske forfattere. 
Cane kritiserer overtro og fanatisme (specielt $\mathrm{i}$ "Kabnis"), men alluderer samtidig flittigt til mere eller mindre eksotiske religioner, som katolicisme ("Becky"), judaisme ("Fern”), buddhisme, hinduisme og caraibisk voodoo ("Carma”). Canes eklektiske ikonografi adskiller Sempter-beboernes religiøsitet både fra den ortodokse protestantiske kristendom - betegnet som "en bleghvid sardonisk guds nymodens ord og svage palaver" ("new words and a weak palabra / Of a white-faced sardonic god") $)^{26}$ - og de i 20'ernes sydstater nok så populære evangeliske vækkelsesbevægelser, og konstruerer den i stedet som synkretisk blandingsreligion eller før-kristen intuitiv animisme. I "Fern" forskydes fortællerens seksuelle tiltrækning af titelpersonen således i retning af en oplevelse af "usete ting": "Det ville ikke have overrasket mig hvis jeg havde haft en åbenbaring. Folk har dem i Georgia oftere end man skulle tro." 27 Og i digtet "Georgia Dusk" beskriver Toomer en barbecue, som han tilskriver en urgammel, ceremoniel betydning:

Meanwhile, the men, with vestiges of pomp,

Race memories of king and caravan,

High-priests, an ostrich, and a juju-man,

Go singing through the footpaths of the swamp

Their voices rise .. the pine trees are guitars,

Strumming, pine-needles fall like sheets of rain..

Their voices rise .. the chorus of the cane

Is caroling a vesper to the stars.

O singers, resinous and soft your songs

Above the sacred whisper of the pines,

Give virgin lips to cornfield concubines,

Bring dreams of Christ to dusky cane-lipped throngs. ${ }^{28}$

“Georgia Dusk" placerer Sydens folkereligion i implicit kontrast til modernitetens desakralisering af verden, som både arkaisk overlevering og holistisk alternativ. Mændenes sange blandes med lydene af fyrretræer og sukkerrør og inviterer landsbyboerne til en "aftenbøn” (“vesper”), som både er dionysisk og andægtig, amerikansk og afrikansk, hedensk og kristen. Sempter-borgernes oplevelse af det hellige beror ikke på overleveret lærdom eller abstrakt teologi, men udleves gennem arbejdet, i konkret reciprocitet med den organiske verden, der opleves som både immanent og transcendent. Der er måske $\mathrm{i}$ virkeligheden knap tale om en religion, men snarere om en arketypisk "kosmisk liturgi", som manifesterer sig rumligt $\mathrm{i}$ naturen og tidsligt $\mathrm{i}$ årstidernes skiften, samt $\mathrm{i}$ de fester og højtider, hvormed mennesker markerer deres deltagelse i denne cyklus. ${ }^{29}$ Sanselighed og åndelighed udelukker ikke hinanden, men forbindes og går op i en højere enhed. Præstegerningen er endnu ikke udskilt fra samfundslivet som en specialiseret arbejdsfunktion, men er en rolle, som både mænd og kvinder kan påtage sig, når den rette ånd kommer over dem. "Folk har [åbenbaringer] i Georgia oftere end man skulle tro," forklarer Toomer, for "når man er på ens forfædres jord er der næsten ingen grænser for hvad der kan hænde én.” ${ }^{\circ}$ Den dagligdags bevidsthed og den ekstatiske vision adskilles kun af en tynd membran, som brydes, når fortælleren ser Fern bryde ud i sang og siden besvime i en sukkerrørsmark, eller når lægprædikanten Barlo i "en religiøs trance" hævder at have set den genfødte Jesus som efterkommer af sorte slaver. ${ }^{31}$

V

Provinsen og det provinsielle var umådeligt populære topoi i europæisk kultur i begyndelsen af det 20. århundrede - ikke mindst blandt formbevidste "modernister." Som kunsthistorikeren Jill Lloyd skriver i sin bog om Emil Nolde og den tyske ekspressionisme, "var modernismen og den folkedyrkende konservatisme ikke skarpt adskilte fænomener, men snarere parallelle udviklinger inden for den samme historiske kontekst." ${ }^{2}$ Den rodfæstede bonde og hans "mystiske sjæl" 33 var emnet for talrige litterære fremstillinger beregnet for et overvejende urbant publikum, hvoraf Knut Hamsuns Nobelprisbelønnede Markens grøde (19I7) blot var den internationalt mest berømte, berygtede og indflydelsesrige. Den (anti-)moderne provinslitteratur registrerer kulturens byrde og protesterer mod moderniseringens affortryllelse af verden, parallelt med og under indflydelse af de mangfoldige "alternative" livsreform- 
bevægelser som florerede i perioden - fra natur-, dyre- og hjemstavnsbeskyttelse til vegetarianisme, kollektivisme, kropskultur og reformpædagogik. Og som i Europa, således også i USA, hvor samtidslitteraturens usunde fascination af det utidssvarende, tilbagestående og arkaiske faldt adskillige kommentatorer for brystet. F.eks. beklagede F. Scott Fitzgerald sig i et brev til sin forlægger Maxwell Perkins i 1925 over dyrkelsen af "Den Enkle og Fåmælte Bonde," hvilket han opfattede som "en stædig søgen efter det statiske, i en verden som i næsten hundrede år ganske enkelt ikke har været statisk." 34

Fitzgerald havde god grund til skepsis, for agrarmodernismen er fyldt med ideologiske faldgruber. Hamsun kollaborerede som bekendt med nazisterne, og sydstatsagrarerne i Nashville bekendte ideologisk kulør, da de i 1930 'erne indledte et tvivlsomt samarbejde med den højreradikale Seward Collins' American Review. 35 Toomers Cane gennemsyres af den samme "romantiske antikapitalisme", som allerede i samtiden ansporede grundlæggerne af Frankfurtskolen til en indigneret polemik mod alle former for livsfilosofisk bonderomantik og naturhengivelse. Ifølge Leo Löwenthal udtrykker det småborgerlige provinssværmeri, som han finder klarest udtrykt hos Hamsun, "en længsel efter en sfære hvor de samfundsmæssige produktivkræfter er bragt til ophør." ${ }^{6}$ I et essay fra 1934 harcelerer Herbert Marcuse ligeledes mod en "irrationalistisk naturalisme", som, når den ophæves til dogme, danner modsætningen til "ansvarlig, autonom, rationel praksis":

I kølvandet på denne naturalisme følger en lovprisning af bønderne som den eneste stand der stadig er "naturforbundet": de fejres som "skabelsens urkilde," som samfundets evige fundament. Den mytiske forherligelse af landbrugets genopblomstring modsvares af kampen mod storbyen og dens "unaturlige" ånd; denne kampagne udvider sig til et angreb på fornuftens herredømme generelt og resulterer i en løssættelse af alle irrationelle kræfter. 37

Det har ikke skortet på ideologikritiske indvendinger over for Toomer, som ofte og ikke uden en vis ræson har måttet se sig tiltalt for eskapisme, idealisme, ahistoricisme og irrationalisme. ${ }^{8}{ }^{8}$ stedet for at gentage denne kritik vil jeg her afslutningsvis, og kun alt for lapidarisk, skitsere en alternativ tilgang til Toomers provinskonstruktion, som tager udgangspunkt i Ernst Bloch, en anden tysk tænker fra samme periode, hvis stil og sensibilitet på mange punkter minder bemærkelsesværdigt om Toomers.

Blochs livslange projekt var at gennemføre en filosofisk rehabilitering af den utopiske tankegang, og til dette formål tilvirkede han en gnomisk, aforistisk og associativ diskurs tydeligt inspireret af den modernistiske avantgarde.39 I 20'erne og 30'erne beskæftigede Bloch sig indgående med den modernitetskritiske antikapitalisme, som netop i mellemkrigstiden blussede op inden for både høj- og populærkulturen. Ved udgivelsen af Erbschaft dieser Zeit (1935) var sådanne "völkisch" strømninger for længst kanaliseret i en bestemt politisk retning, idet den fascisme, som eksilerede Bloch i Schweiz, havde gjort sig til talsmand for "traditionelle" værdinormer. Bloch gennemskuede dette bedrageri, og han begræd de "progressive" kræfters uvilje til at genbesætte det tabte territorium. I modsætning til den på venstrefløjen dominerende fremskridtsdeterminisme var Bloch villig til at tale romantikkens sprog, ikke blot af rent pragmatiske årsager, fordi han på den vis håbede at italesætte tilsyneladende fortabte dele af befolkningen, men også fordi han mente at primitivismens, vitalismens og provinsialismens patetiske figurer - "Natur," "Boden", "Land," "Volk" - udgjorde en værdifuld arv ("Erbschaft"), som ikke uden videre burde overlades til højrepropagandaen. I Erbschaft ironiserer Bloch over den moderne storbyfjendtligheds "pastorale militans," som nok dyrker "jordens myte," men som skyr "virkelig arkaiske tilstande" som "fælles ejendom" eller "fælles jordbesiddelse." ${ }^{\circ}$ Men samtidig kunne han, som led i I930'ernes "ekspressionismestrid" med vennen Geörgy Lukacs i tidsskriftet Das Wort, forsvare den genuint chiliastiske impuls hos malerne fra kunstnersammenslutningen Der blaue Reiter.4I Den moderne pastorales drøm om et alternativ før, uden for eller hinsides det moderne består ikke udelukkende af "reaktionære" ("rückständig") fantasmagoria, for sådanne tankeformer karakteriseres ifølge Bloch af en iboende "usamtidighed" ("Ungleichzeitigkeit"), 
som betyder, at de på én gang peger fremad og tilbage. Kategorien "at være hjemme" ("die Kategorie des Zuhauseseins"), forklarer Bloch i et senere interview, bør forstås som "en gammel og filosofisk og også mystisk kategori uden dårlig bismag.” Selv et belastet begreb som "Heimat" kan bringes til at afsløre et dybereliggende "utopisk moment," som dialektikken beklageligvis har forsømt at anskueliggøre og videreudvikle. ${ }^{2}$

Toomers forbehold over for det moderne industrisamfund allierer ham $i$ et vist omfang med de andre agrarmodernister, men i forhold til Tate, Heidegger, Nolde eller Hamsun kan Toomer kun langt vanskeligere indpasses som "reaktionær modernist." 43 Det er i det hele taget vanskeligt at forestille sig en mere "usamtidig" tekst end Cane. I et selvbiografisk fragment distancerede Toomer sig fra de "romantikere" og "eskapister", som "forsøgte at helbrede sig selv ved en tilbagevenden til mere primitive forhold," idet han understregede, at selv om "den moderne verden var rodløs, var ved at falde sammen [...] kunne vi ikke vende tilbage [...] hvad enten vi ønskede det eller ej blev vi nødt til at fortsatte." 44 I Cane taler "Song of the Son" rigtignok om muligheden for tilbagevenden til det førmoderne:

O land and soil, red soil and sweet-gum tree,

So scant of grass, so profligate of pines,

Now just before an epoch's sun declines

Thy son, in time, I have returned to thee,

Thy son, I have in time returned to thee. 45

Men den tredje del af Cane, det absurdistisk-selvbiografiske enaktsdrama "Kabnis," kan læses som en selvrefleksiv satire over den selvsamme længsel efter "land and soil." Hovedpersonen Ralph Kabnis er prototypen på den splittede nordstatsintellektuelle "Nye Sorte," som er vendt tilbage til Syden for at finde sine rødder i et idealiseret, sort agrarsamfund:

Han tvinger sig selv til at fokusere på en hytte opført på en bakke omtrent en mil væk. De sorte indenfor er tilfredse. De dyrker jorden. De synger. De elsker. De sover. Kabnis overvejer om de måske kan føle ham. Om han måske giver dem onde drømme. Tingene er så umiddelbare i Georgia. $4^{6}$
Kabnis drømmer om forløsning gennem en reetableret kontakt med "bomuldens land", men de mennesker, han møder, forekommer ham tarvelige erstatninger for den renhed, han har forestillet sig. Den fortabte søn isolerer sig i sin lejlighed, og det lykkes ham aldrig at falde ind i gammellivets rytme; han forbliver tværtimod "afskåret fra alt," "rodløs [...] svævende nogle fă fod over den jord hvis berøring ville lade ham genopstå." 47 Paralyseret af "magtesløs nostalgi” fyres han først fra sit job som skolelærer, men får en ekstra chance, da karetmageren Hayley tager ham i lære..$^{8}$ Også denne mulighed for at lære et ærligt håndværk sætter Kabnis dog over styr, og hans generobringstogt kuldsejler antiklimatisk og tragikomisk i et gigantisk surreelt drikkeorgie.

$V I$

"Vi kunne vi ikke vende tilbage [...] vi blev nødt til at fortsatte": Cane skuer ikke blot tilbage, men indeholder også stærke elementer af fremadrettet tilsynekomst - hvad Bloch kalder "Vor-Schein." 49 Toomer forbinder provinsen med naturgroet oprindelighed, men også med utopisk frigørelse, ikke blot fra alskens kristne syndefaldsmyter, moralbegreber og dualistisk skelnen mellem krop og sjæl, men også fra den i USA mest betydningsfulde identitetskategori af alle: race. I årene efter Cane bevægede Toomer sig stadig længere ud på det nyreligiøse overdrev, og i takt med hans fordybelse i Gurdjieff-bevægelsen trak han sig gradvist tilbage fra den etablerede litterære scene. I det eneste af Toomers senere værker, som slog an, det lange Whitman-inspirerede epos "Blue Meridian" (1930-36), fortsætter Toomer sit angreb på det 20. århundredes industrielle dekadence, idet han afbilder den moderne amerikanske ørn, oprindeligt “en ophøjet og blodig fugl," som en selvdestruktiv Ikaros eller Lindbergh-skikkelse i en beskadiget flyvemaskine på kurs mod et uafvendeligt "Crash!” ${ }_{50}$ Men samtidig besynger Toomer i højstemte toner en dybere historisk determinisme, som ifølge hans profeti langsomt, men sikkert, vil opløse gamle forskelle, udrydde tidligere konflikter og føre til skabelsen af "et nyt Amerika." ${ }^{1}$ Det springende punkt i denne okkulte mytologi er Toomers ide om en gradvis, allerede igangværende udviskning af forskellene 
mellem "hvide," "sorte" og "røde" racer, som vil kulminere i etableringen af en ny hybridiseret mennesketype i Amerika:

Black is black, white is white,

East is east, west is west,

Is truth for the mind of contrasts;

But here the high way of the third,

The man of blue or purple,

Beyond the little tags and small marks,

Foretold by ancient seers who knew,

Not the place, not the name, not the time,

But the aim of life in men,

The resultant of yes and no

Struggling for birth through ages..$^{2}$

Toomers messianske forestilling om en "blå eller violet" menneskehed betones noget mere tentativt $\mathrm{i}$ Cane, som hermed viser sig at være en mindre entydigt "sort" tekst end ofte antaget. George Hutchison har påpeget, hvordan Toomer, som altid understregede sin egen blandede familiebaggrund, "dramatiserer det nye etniske subjekts pinefulde 'tusmørkefør-daggry,' hvis eksistensmulighed afvistes af både 'hvide' og 'sorte' definitioner af racemæssig subjektivitet."'53 Den raceblandede seksualitet florerer rigtignok i Canes provinsmiljø, på trods af utrættelige brutale forsøg på at tabuisere og disciplinere den. Racemæssige grænser overskrides, forsøges genoprettet og overskrides igen i noveller som "Fern," "Becky," "Blood-Burning Moon" og måske mest bemærkelsesværdigt i digtet "Portrait in Georgia":

Hair - braided chestnut,

coiled like a lyncher's rope,

Eyes - fagots,

Lips - old scars, or the first red blisters,

Breath - the last sweet scent of cane,

And her slim body, white as the ash

of black flesh after flame. 54

Med forbilledlig poetisk økonomi sammensmelter Toomer her portrættet af en hvid kvinde med billedet af en lynchet sort mand, antagelig dræbt som følge af en sort-hvid seksuel liaison. Digtet markerer ikke blot en protest mod den ekstreme grusomhed som udøves $\mathrm{i}$ forsøget på at håndhæve racemæssige distinktioner, men også en formel gestaltning af den grænseoverskridende, progressive dynamik, som ifølge Toomers historiefilosofi altid-allerede vil få det sidste ord.

I forordet til Geist der Utopie (I9I8) ansporer Bloch sine lasere til "at bygge ind $\mathrm{i}$ det blå, at bygge os ind i det blå og søge det sande og virkelige dér hvor det blot faktiske forsvinder - incipit vita nova." 55 Toomers Cane hjælper os til at forstå agrarmodernismens provinskonstruktioner som andet og mere end "reaktionær" ønsketænkning, for det imaginære Sempter, Georgia, leverer ikke blot et idealbillede på det gamle landbrugssamfunds dyder, men også en kryptisk vision om en ny "blå" mennesketype, hvis dag endnu ikke er gryet. Tekstens modernistiske dobbelttydighed ligger $i$, at den på én gang restaurerer det førmoderne agrarsamfund og leger med håbet om en mystisk genfødsel af menneskeheden i det postmoderne. Det er passende, at Cane ender med en solopgang:

Udenfor hæver solen sig fra sin vugge i skovens trætæppe. Skygger af fyrretræer er drømme som solen ryster fra sine øjne. Solen står op. Som et guld-glødende barn træder den ind i himlen og sender en fødselssang skråt ned af sydstatsbyens gråstøvede gader og søvnige vinduer. $5^{6}$

Noter

I. Fredric Jameson: "Ulysses in History" in W. J. McCormack og Alistair Steads: James Joyce and Modern Literature (London, 1982), I30.

2. Malcolm Bradbury: "The Cities of Modernism" in Malcolm Bradbury og James McFarland: Modernism 189o1930 (London, I976), 96.

3. Hans Hauge: forord, D. H. Lawrence: Åbenbaring (København, 1996), 5 .

4. Norbert Mecklenburg: Erzählte Provinz: Regionalismus und Moderne im Roman (Berlin, I986), 7.

5. Martin Heidegger: "Warum bleiben wir in der Provinz?" in Nachlese zu Heidegger: Dokumente zu seinem Leben und Denken (Bern, I962), 216-I8.

6. Faulkners voluminøse forfatterskab byder kun på én decideret byroman, den dystopiske Pylon (1935), som foregår blandt flyakrobater i et depressionsramt "New Valois, Franciana" (New Orleans, Louisiana).

7. Allen Tate: "Negro Poetry" in The Poetry Reviews of Al- 
len Tate 1924-44 (Baton Rouge, 1983), 22.

8. Se Michael North: The Dialect of Modernism: Race, Language, and Twentieth-Century Literature (Oxford, I992).

9. Ezra Pound: Make It New (London, 1934).

Io.Jean Toomer: A Jean Toomer Reader (New York, I993), I6.

II. Toomer: Cane (New York, I988), I5I.

12. Toomer: The Wayward and the Seeking: A Collection of Writings by Jean Toomer (Washington, I980), I23.

I3. Toomer: Cane, I5I.

I4. A Jean Toomer Reader, 233.

I5. Charles R. Larson: "Cane by Jean Toomer" in The New Republic, I9 June 1976, 3I-32.

I6. Se Ann Marie Bush and Louis D. Mitchell: "Jean Toomer: A Cubist Poet" in Black American Literature Forum I 7.3 (1983), 106-8.

I7. Se Barbara Foley: “'In the Land of Cotton': Economics and Violence in Jean Toomer's Cane" in African American Review 32 (I998), I8I-98.

I8. Toomer: Cane, I39.

I9. Se William H. Ramsay, "Jean Toomer's Eternal South" in The Southern Literary Journal 36 (2003), 74-89.

20.Se T. S. Eliot: "Ulysses, Order, and Myth" in Selected Prose (London, I975), I78.

2I. Toomer: Cane, II.

22.Ibid., I7.

23. Ibid., 2.

24.Ibid., I3.

25.Ibid., I7.

26.Ibid., 28 .

27. Ibid., 9.

28.Ibid., I5.

29. Mircea Eliade: Helligt og profant: Om religionens vasen

(København, I965), I23.

30. Toomer: Cane, 19.

3I. Ibid., 22.

32.Jill Lloyd: German Expressionism: Primitivism and Modernity (New Haven, 1991), IIo.

33. Oswald Spengler: Der Untergang des Abendlandes (München, I922), bd. 2, II3.
34. Citeret i J. Albert Robbins: "Fitzgerald and the Simple, Inarticulate Farmer" in Modern Fiction Studies 7 (I962), 365 .

35. Allen Tate udgav bl.a. en essaysamling med den sigende titel Reactionary Essays on Poetry and Ideas (New York, 1936).

36. Leo Löwenthal: "Knut Hamsun: Til den autoritære ideologis forhistorie" in Om Ibsen og Hamsun (Oslo, I980), 66. Löwenthals tekst tryktes først i Zeitschrift für Sozialforschung i 1937 som "Knut Hamsun: Zur Vorgeschichte der autoritaren Ideologie."

37. Herbert Marcuse: "Der Kampf gegen den Liberalismus in der totalitären Staatsauffassung" in Kultur und Gesellschaft (Frankfurt, 1970), bd. I, 36.

38. Se f.eks. Donald B. Gibson: The Politics of Literary Expression: A Study of Major Black Writers (Westport, I98I), I77.

39. Se især Ernst Bloch: Geist der Utopie (Frankfurt, I975). 40.Bloch: Erbschaft dieser Zeit (Frankfurt, 1962), 54-55.

4I. Ibid., 255-66.

42. Gespräche mit Ernst Bloch (Frankfurt, 1975), 206-7.

43. Dette begreb udvikles af Jeffrey Herf i Reactionary Modernism: Technology, Culture, and Politics in Weimar and the Third Reich (Cambridge, 1984).

44. Toomer: The Wayward and the Seeking, I29.

45. Toomer: Cane, I4.

46. Ibid., 86 .

47. Ibid., 89, 98 .

48. Ibid., 86.

49. Se Bloch, Ästhetik des Vorscheins (Frankfurt, 1974).

50. Toomer: "The Blue Meridian" in The Collected Poems of

Jean Toomer (Chapel Hill, I988), 57-58.

5 I. Ibid., 50.

52.Ibid., 74 .

53. George Hutchison: "Jean Toomer and American Racial Discourse" in Texas Studies in Literature and Language 35 (I993), 23I.

54. Toomer: Cane, 29.

55. Bloch: Geist, 9.

56. Toomer: Cane, II7. 